\title{
The Power of Words: Inmates Write Stories of Life and Redemption
}

\author{
Diane Ketelle \\ Mills College, \\ USA
}

\section{Introduction}

Prison is a place of uncertainty where the narratives of those incarcerated unfold. For most of the students I encountered in the writing workshop I formed at San Quentin State Prison, prison was a place of waiting, where anger is muted and friendships are forged across unlikely boundaries. Within this dehumanizing context, writing becomes an act of therapy, resistance and community building. It can also be a dangerous act because it encourages the remaking of selves despite confinement.

San Quentin State Prison, the oldest, largest and only death row prison in California. Opened in 1852, the prison is located in Point San Quentin, a village with its own zip code, on luxurious waterfront property valued at upwards of \$664 million (Department of General Services, 2001). The prison was built with a capacity to hold 3,302 inmates, but in recent years it has held as many as 5, 247 (San Quentin State Prison, 2009).

In 2010,1,404,053 persons were incarcerated in state and federal prisons in the United States (Pew Center, 2010). Approximately 1 in 100 adults is living behind bars in America (Public Safety Performance Project, 2008). Most of my students have been African American, Latino or Native American. In the United States the differential rate of imprisonment of AfricanAmericans to Caucasians, proportional to population is in excess of 7.5 to 1 (U.S. Bureau of Justice Statistics, 20010). The differential rate of imprisonment of Latinos to Caucasians is about 5 to 1 (U.S. Bureau of Justice Statistics, 2010). Annually, over 700,000 inmates are released from prison to home. A recent study by the California Department of Corrections and Rehabilitation notes that most California parolees are back in prison in three years (Egelko, 2010). The same study notes a decline in imprisonment within the first year of release, but finds that the three year recidivism rate has increased. The study found that $70 \%$ of imprisonments over the past three years were for parole violations rather than convictions, and that the highest recidivism rate, $75 \%$ over three years, was for parolees ages 24 and younger. Although the incarcerated wait to be released, when released they often set off on paths that return them to prison.

I taught a writing workshop at San Quentin after volunteering for five months in a prison classroom. As a classroom volunteer I taught writing to thirty or forty students at a time for one or two hours per week. This teaching helped me establish strong relationships with students, but it precluded the opportunity for the men to develop as writers and as a 
community. I switched formats and began holding a writing workshop for three hours per week in 12 week sessions. Participants voluntarily signed up to participate in the workshop. Each workshop had ten to fifteen men, but because prison life is transitory, a number of men would stop in each week, so the group consistency changed constantly. Within each 12 week session a core group of students would take shape, and from that core frequently emerged leadership and strong writing.

Students in the writing workshop were supported by the writing group as they created and maintained their intellectual and creative selves through writing about their lives. Inmates, often with the help of projects such as this one, can maintain and fortify their lives inside prison through writing, and participating in critical discourse. In these ways inmates practice a way of living that is creative and forward looking in the face of daily violence and systematically produced hopelessness. Much of the writing produced in the workshop was raw and immediate which was connected to the writing community we created together.

\section{Writing the self}

Each week I sat around a table in a prison classroom with my students in the $\mathrm{H}$ unit of the prison. The writing that emerged had some general similarities. In writing about their lives each author was writing with an insistence that his voice mattered and often sought redemption from many regretful actions through reflection. In this way the writing became a way of constructing the self within a community, contributing to the greater good of the writing group, and helping authors create new meaning from their life experiences. Although the men were encouraged to get along as a community in prison, many of our discussions focused on individualism and the redemption of individual lives, as well as the return to their families. The inmates survived under conditions that would break most of us on the outside in far less time than they endured them, but through writing it was possible for them to uncover new perspectives on themselves.

Life stories, such as the ones that emerged in the workshop, offer insight into how a person has come to be who they are. Inmate writing focused on every stage of life from childhood to adulthood. Autobiographical narratives of this sort are not intended to convey the reality of what happened in the past (Schacter, 1996), since life stories communicate more about what is going on for a person in the present (McAdams, 2006). In this way, this kind of writing is personal as opposed to the mere documentation of actual events (Bruner, 1990; Cohler, 1982; McAdams, 1985). Such stories exist as evolving narratives of the self that portray how a person understands her or himself in the moment, or who she or he could become in the future (Bruner, 1990). Through constructing narratives individuals are trying to understand the present and construct a future they can inhabit.

When inmates have the opportunity to be a part of a writing community, that community takes on a heightened sense of urgency and importance. Students wrote about any topic that was of interest. Part of our class was devoted to writing exercises, while the other part was given to sharing stories that were written inside and outside of class. Students wrote about their experiences as a powerful way of expressing their agency and power in an environment that denied both. The act of writing, in this way, assisted students in envisioning new life themes and plots. 


\section{Redemption stories}

Students wrote stories for their children, parents, grandparents, lovers, spouses, and friends. Many times these stories were expressions of sorrow, love, redemption and hope. McAdams (2006) notes, "redemption is the deliverance from suffering to an enhanced status or state" (p. 88). McAdams further notes that redemptive stories do more than make sense out of a life, "They reflect social norms, gender stereotypes, historical events, cultural assumptions, and the many and conflicting narratives that people grow up with and continue to hear, experience, appropriate, and reject as they move through the life course; and life stories about how to live replace old ones" (p. 95). Our lives, then, are heavily influenced by how we understand events through the stories we construct.

Kenny Gonzales, a 42 year old Latino incarcerated for dealing drugs, attended the workshop for two years. His story, A Happy Thought, focused on a trip he took to Disneyland with his daughter. In this story Kenny focuses on the wide gap between the way the world is and was, and the way it should be now. The story adopts a firm tone of compassion as Kenny strives to paint a portrait of a time in the past.

The memory is so strong I can all but touch it. We were down in Anaheim doing the Disneyland thing. This was not out first trip there and I had learned to take a day off and just hang out at the motel. We weren't staying at the Disneyland Hotel, but we found plenty of things to do. First, we went to McDonalds for breakfast and what tenyear-old doesn't like McDonalds? My daughter had pancakes. I had the smile on her face. Then it was back to the room for some TV and jumping on the bed. We were having a great time and I could not believe how much she was enjoying the movie that was on, Hot Shots Part Two. Lunch time and we were back at McDonalds. After that it was pool time, something we both enjoyed there or at home. A much more physical experience for me than for her, as she loved the crazy inflatable dolphin toy. A silly thing I got to entertain her. It was a beautiful day.

Kenny's story affirms the power of testimony in healing from trauma (Kenyon \& Randall, 1997). Events in his story are arranged according to their chronological order as his memories are explored through the language used. His description helps to employ imagination in cobbling his story together. What can he do when what is and what ought to be do not match up? This is the foundation of the simplest moral experience and it is bound to understanding an experience and forming ideas about it.

What we did next only she could save me from. We knew there was a miniature golf course down the road. The walk after being in the pool was one thing, but the heat was another. Like always she made it fun. She made me understand that all my time with her was precious and I knew then that I was living a special memory, a special moment, and a special time. A moment I have obviously kept with me for 17 years and will retain until my mind or body goes. We made it there and back in one piece enjoying every second of it. We went for a dip in the pool and settled in for some more TV. We ordered a pizza, salad, wings and sodas consuming them at our leisure. Then just about 9:00 PM we put our chairs just outside our room to watch the fireworks from Disneyland. When the fireworks were done, so were we. Never before and not since have I gone to bed and sleep so contently. 
Prison can be a place where people shut down internally, but in this story Kenny rises above that reality and seeks a new understanding from his life. In the final paragraph of his story Kenny offers insight into his second chance or redemption.

My reason for sharing this story is simple. Naturally, I love my daughter so much, but more importantly all who read this story will have a chance to at least feel the kind of clarity that my daughter gave to me. The wisdom to understand it isn't always about what is next. She taught me to live in the moment because this is our only to chance. The lesson I learned from her was to never look back wondering where the time went. Instead, I live life to the fullest and will learn what I can.

Kenny learned through the process of writing this story that he is not alone and he learned that with and from other detainees in the writing workshop. He acknowledges with grace that his daughter helped him make sense of his life story. Personal writing, like Kenny's story, has a function of preserving personal identity inside the rigid, uniform prison walls. For Kenny, this story evidences his acceptance of his situation and his desire to strive to be a better person. He tells us to "live life to the fullest" and not wait to love or care because circumstances can change. This is Kenny's deliverance and the reader is provided a window into Kenny's enhanced state of appreciation for what life has to offer him in a future, something he is beginning to imagine.

John Peter Wilks, a 50 year old African American incarcerated for drug dealing, wrote about his girlfriend Robin, who died from a drug overdose in My Red Headed Dead Head. He writes:

I was hysterical when I found out that my girlfriend, Robin, was in the hospital. Based on the phone call I received from her friend Rebecca, I had loosely gathered that Robin and Rebecca had started shooting up again. They had been renting a room at one of the run down Pakistani hotels in the Mission. Unbeknownst to me these illicit meetings had been occurring for almost a month right under my nose. The whole time I had the impression that Robin was on her daily methadone maintenance which she had begun earlier in the year. It was I who had walked with her hand in hand to the detox clinic. I was so proud of her decision to quit heroin. Our mutual friends had told me it was only a matter of time before she started using again, but I wouldn't listen. I had faith in her and now she was in the hospital.

As John Peter begins his story his struggle emerges. It is unlikely that he did not know that his girlfriend had begun using, but for the purposes of the story, and for processing his pain, he casts himself at a distance. Doing this allows him to reflect by taking a new point of view. Later in the story he writes:

Someone tapping on my shoulder woke me. I opened my eyes and there was a young woman kneeling beside me. She was wearing a cap and a paper surgical mask over her mouth. Her scrubs had little pictures of Sponge Bob Square Pants. She unsnapped her mask and removed her cap. She had dark hair and sympathetic hazel eyes topped with long eye lashes. She told me her name was Dr. Tendler. I didn't think I could handle what she was about to tell me. With a deep sigh she told me that Robin had developed an abscess from her drug use. Apparently, the abscess killed her. Robin neglected seeking medical attention. They had tried a transfusion. They did all they could. She was deeply sorry for my loss. 
Faced by this dauntingly sad experience John Peter allows the story to give way to an experience of growth in the end:

Whenever I'm in the Mission acquaintances of Robin, who are practically strangers to me, still approach me and offer their heartfelt condolences. It has been suggested that I should write about her death in depth and maybe one day I will. I will start that story on the day that Robin's best friend, Rebecca, and I started our recovery. We became clean and sober the day Robin died.

Although devastated by Robin's death, John Peter emerges from the experience with renewed confidence that it is possible to overcome drug addiction. Although we know his recovery was not successful, since his drug addiction ultimately sent him back to prison, in writing the story of Robin, John Peter is demonstrating renewed agency and hope that he will make a new life upon his release. We can only hope that he will be successful.

Seeking redemption in the prison context has intense meaning. Inmates are marginalized and forgotten by loved ones and society. Finding hope under such circumstances delivers them from their oppressive mistakes and life experiences. Unlike McAdams (2006) who argues redemption stories contain specific elements, the redemption stories in this workshop took on no particular form or pattern, but instead were identified by an orientation to a hopeful future and a desire to change a future self through forgiving and remaking the past.

\section{Conclusion}

Writing and constructing life narratives provides meaning and purpose while providing explanations for the decisions a person has made. Any kind of life story can help a person construct new meaning. In the two stories shared in this chapter the writers approached redemption in slightly different ways. Kenny wrote an idealized memory and transmitted his desire to live in the moment and appreciate all life has to offer revealing his desire to embrace a new way of living. This is a revelation in understanding his life. John Peter constructs a redemptive story that focuses on death and rebirth as his story turns to redemption as his commitment to overcome his drug addiction is revealed. These stories are examples of narrative self-making (McAdams \& Bowman, 2001) and through writing these stories Kenny and John Peter were able to construct their future selves in preparation of their release.

At a time when local economies are collapsing, the prison industry continues to grow. This increases the importance of writing projects in prisons. Prison policies are often based on distorted stereotypes that effect the experiences of inmates. Writing in the prison context does more than keep inmates going, it helps recreate their lives through reflection and meaning making. This project, which falls in the tradition of social science life writing, gave writers voice and an opportunity to write their stories. By learning about and listening to their stories we can understand how each person struggles to construct their life through words.

\section{References}

Bruner, J. (1990). Acts of mind. Cambridge, MA: Harvard University Press. 
Department of General Services (2001).Preliminary analysis of potential reuse and relocation of San Quentin. State of California. Retrieved February 2, 2011:

www.documents.dgs.ca.gov/legi/publications/2001/reports/preliminary.html

Cohler, B. (1982). Personal narrative and the life course. In P. Baltes \& O. Brim (Eds.), Lifespan development and behavior (pp. 205-241). New York Academic.

Egelko, B. (2010). Back in prison in three years, San Francisco Chronicle, November 4, 2010. Retrieved on November 4, 2010 at: http://www.sfgate.com/cgi-bin/article.cgi?file=/c/a/2010/11/04/BA2FIG6GNV.DTL

Kenyon, G. \& Randall, W. (1997). Restorying our lives: Personal growth through autobiographical reflection. Westport, CN: Praeger.

McAdams, D. (1985). Power, intimacy and life story. New York: Guilford.

McAdams, D. (2006). The redemptive self: Generativity and the stories Americans live by, Research in Human development, 3(2 \& 3), 81-100.

McAdams, D. \& Bowman, P. (2001). Narrating life's turning points: Redemption and contamination. In D. McAdams, R. Josselson \& A. Lieblich (Eds.), Turns in the road: Narrative studies of lives in transition (pp. 3-34). Washington: American Psychological Association.

Pew Center on the States (2010). Prison count 2010. The Pew Charitable Trust. Retrieved on January 22, 2010:

http://www.pewcenterforthestates.org/uploadedFiles/Prison_Count_2010.pdf.

San Quentin State Prison (2009). Institutional statistics. Sacramento, CA: California Department of Corrections and Rehabilitation.

Schacter, D. (1996). Searching for memory. New York: Basic Books.

United States Bureau of Justice Statistics (2010). Prisoners in 2010. Washington D.C.: United States Bureau of Justice Statistics. 
(C) 2012 The Author(s). Licensee IntechOpen. This is an open access article distributed under the terms of the Creative Commons Attribution 3.0 License, which permits unrestricted use, distribution, and reproduction in any medium, provided the original work is properly cited. 